\title{
A two-dimensional CFD model for heap bioleaching of chalcocite
}

\author{
M. J. Leahy* ${ }^{\dagger} \quad$ M. R. Davidson* M. P. Schwarz ${ }^{\dagger}$
}

(Received 21 October 2004, revised 12 May 2005)

\begin{abstract}
A 3-phase computational fluid dynamics (CFD) model for heap bioleaching of chalcocite is investigated to identify and understand the effect of oxygen flow during air sparging. The study uses an existing one-dimensional model of liquid flow, bacterial transport (including attachment/detachment of bacteria to ore particles), and the depletion of a copper-sulphide, coupled with a two-dimensional model of gas flow in the heap. The CFD model includes the effects of oxygen and ferrous ion consumption, coupled with leaching of copper-sulphide via a shrinking core model. The model is used to investigate the twodimensional effects of air flow in heap bioleaching with regard to oxygen limitation. Under oxygen limitation, copper leaching is found to
\end{abstract}

*Dept. Chemical and Biomolecular Engineering, The University of Melbourne, Melbourne, Australia. mailto:martin.leahy@csiro.au

${ }^{\dagger}$ Commonwealth Scientific and Industrial Research Organization, Division of Minerals, Clayton, Australia.

See http://anziamj.austms.org.au/V46/CTAC2004/Leah for this article, (C) Austral. Mathematical Soc. 2005. Published June 3, 2005. ISSN 1446-8735 
occur from the bottom up, successively leaching the oxygenated regions and moving slowly up the heap to leach the whole bed. Some experimental validation is provided.

\section{Contents}

1 Introduction

C440

2 Model

C443

2.1 Model formulation . . . . . . . . . . . . . . . . . C443

2.2 Boundary and initial conditions . . . . . . . . . . . C447

2.3 Numerical considerations . . . . . . . . . . . . . . . . C448

3 Results and discussion

C449

3.1 Experimental validation . . . . . . . . . . . . . . C449

3.2 Model results . . . . . . . . . . . . . . . . . . C450

4 Conclusion

$\mathrm{C} 454$

References

C455

\section{Introduction}

Heap bioleaching is an important extraction process used in the removal of metals such as copper and zinc from low grade ores. The ore used in heap bioleaching is typically low grade $(0.2-2 \%)$ in copper, and as a result the heaps need to be very large (up to a kilometre long, and typically less than $500 \mathrm{~m}$ wide and $10 \mathrm{~m}$ tall) to be economically viable. The leaching process involves the infiltration of sulphuric acid and dissolved iron into the heap, whereby ferric ions in the liquid react with copper sulphide in the ore to produce ferrous ions and copper in solution, which flows out of the heap as a 
product stream. Iron oxidizing bacteria such as Acidithiobacillus ferrooxidans are present in the heap either attached to the ore or free in solution [9], and may occur either naturally or as a result of being seeded in solution. To keep the aerobic bacteria (such as $A$. ferrooxidans) alive, the injection of air into the heap (sparging) is of utmost importance. Oxygen in the air within the heap transfers into the liquid phase, is consumed by bacteria in the liquid, and enhances the process by converting ferrous ions back into ferric ions [11]:

$$
\mathrm{Fe}^{2+}+0.25 \mathrm{O}_{2}+\mathrm{H}^{+} \stackrel{\text { bacteria }}{\longrightarrow} \mathrm{Fe}^{3+}+0.5 \mathrm{H}_{2} \mathrm{O} \text {. }
$$

We consider the copper sulfide chalcocite $\left(\mathrm{Cu}_{2} \mathrm{~S}\right)$, which often naturally occurs with pyrite $\left(\mathrm{FeS}_{2}\right)$. Leaching occurs as a result of ferric ions reacting with the copper sulfide minerals, producing ferrous and copper ions in solution, equation (2), and in the dissolution of pyrite, equation (3):

$$
\begin{aligned}
& \mathrm{Cu}_{2} \mathrm{~S}+4 \mathrm{Fe}^{3+} \longrightarrow 4 \mathrm{Fe}^{2+}+2 \mathrm{Cu}^{2+}+\mathrm{S}, \\
& \mathrm{FeS}_{2}+8 \mathrm{H}_{2} \mathrm{O}+14 \mathrm{Fe}^{3+} \longrightarrow 15 \mathrm{Fe}^{2+}+2 \mathrm{SO}_{4}^{2-}+16 \mathrm{H}^{+} .
\end{aligned}
$$

Mathematical modelling of the heap bioleaching process should account for the heat and mass transfer, liquid and gas flow, and chemical processes occurring. A number of heap and column bioleaching models have been developed in the last decade, with $[12,5,7]$ developing models to include aspects associated with the bioleaching process, such as bacterial growth and movement, sulfide depletion and sulfide oxidizing bacteria, precipitation of ferric ions to jarosite, two stage leaching (for chalcocite), and multiple particle sizes. Complex transient liquid flow models, accounting for liquid holdup and stagnant regions, have also been developed; Bouffard and Dixon [5] developing a 1D Turner Structure model. Bennett et al. [4] discuss a comprehensive 2D liquid flow sub-model in a copper bioleaching model. The only heap bioleaching models to include a comprehensive treatment of transport, growth, attachment and detachment of bacteria together are by Neuburg et al. [12] and Dixon and Petersen [8], as pointed out by Dixon's review [7]. These are 1D models for column bioleaching, and consequently do not include the effect of a 2D geometry, with associated 2D airflow. However, Sidborn and 
Moreno [13] discuss a transient 2D heat and gas flow bioleaching model of chalcocite, which modelled the movement of the solutes ferric ions under advection dispersion (the oxidant); though this model does not account for variation in the bacterial concentration in time or space (unlike this work). Further, Sidborn and Moreno [13] only give a limited parameter analysis of the model and use a sparger spacing varying from $12-20 \mathrm{~m}$, which is unrealistically large to that used in practice (1-4 metres). In addition, Sidborn and Moreno [13] use a high permeability $\left(10^{-9}\right)$, but a real heap the permeability varies from $10^{-9}-10^{-11}$ [3]. This work attempts to overcome these limitations. The circumstances under which 2D airflow are important, are when the oxygen supply limits bacterial growth, which is the topic of this work. These 1D models also take the inoculation process as being a pulse addition of bacteria (with the incoming liquid at the top of the column), and assume a zero initial population of bacteria. However, in real heap bioleaching operations, the heap is likely to have an initial distribution of naturally occurring bacteria, and would not be inoculated via bacterial pulsing as simulated in [8]; in this work, a non zero bacterial concentration is taken as the initial condition, with no pulse addition of bacteria.

The aim of this work is to investigate how the heap leaches under 2D oxygen limitation. The column bioleaching operation is assumed to be isothermal, since such columns will usually have a cooling jacket around the column. In a real heap, isothermal conditions cannot normally be assumed; however, to fully understand the effects of oxygen limitation (the study of this work) isothermal conditions are assumed for simplicity. Hence, bacterial heat production and associated transfer is not taken into account in this model, and is investigated in future work. 


\section{Model}

The process is summarized as follows (as depicted in Figure 1) and is assumed to involve 8 components. The solid phase (assumed to be stationary), contains the un-leached copper remaining in the ore, and is described by a shrinking core model. Bacteria attach and detach to and from the ore within the liquid phase, and have Monod growth kinetics dependent on oxygen and ferrous ions [12]. Oxygen in the gas phase exchanges with the liquid phase. Those species in the (flowing) liquid phase are: oxygen which exchanges with the gas phase; ferrous and ferric ions which are converted back and forth (ferric ions regenerated from bacteria, and ferric ions converted to ferrous ions in leaching); and free bacteria which exchange with the attached bacteria.

\subsection{Model formulation}

The liquid is assumed to flow vertically downwards, so that $v_{L}=q_{L} / \varepsilon_{L}$ where $\varepsilon_{L}$ is the bulk liquid volume fraction and $q_{L}$ is the Darcy velocity of the liquid phase. Within the current CFD framework, the gas flow is described by the Navier-Stokes equations in 2D:

$$
\frac{\partial}{\partial t}\left(\varepsilon_{g} \rho_{g} \mathbf{v}_{g}\right)+\varepsilon_{g} \rho_{g} \nabla \cdot\left(\mathbf{v}_{g} \mathbf{v}_{g}\right)=-\varepsilon_{g} \nabla p+\varepsilon_{g} \nu_{g} \nabla^{2} \mathbf{v}_{g}+\varepsilon_{g} \mathbf{B},
$$

where the body forces are given by the porous media resistivity [2]

$$
\mathbf{B}=-\frac{\varepsilon_{g} \nu_{g}}{K} \mathbf{v}_{g} .
$$

In the Navier-Stokes equations (4), $\mathbf{v}_{g}$ is the gas velocity, $\varepsilon_{g}$ is the volume fraction air void space, $\rho_{g}$ is the air density, $p$ is the air pressure, $\nu_{g}$ is the air viscosity, and $K$ is the bed permeability. 


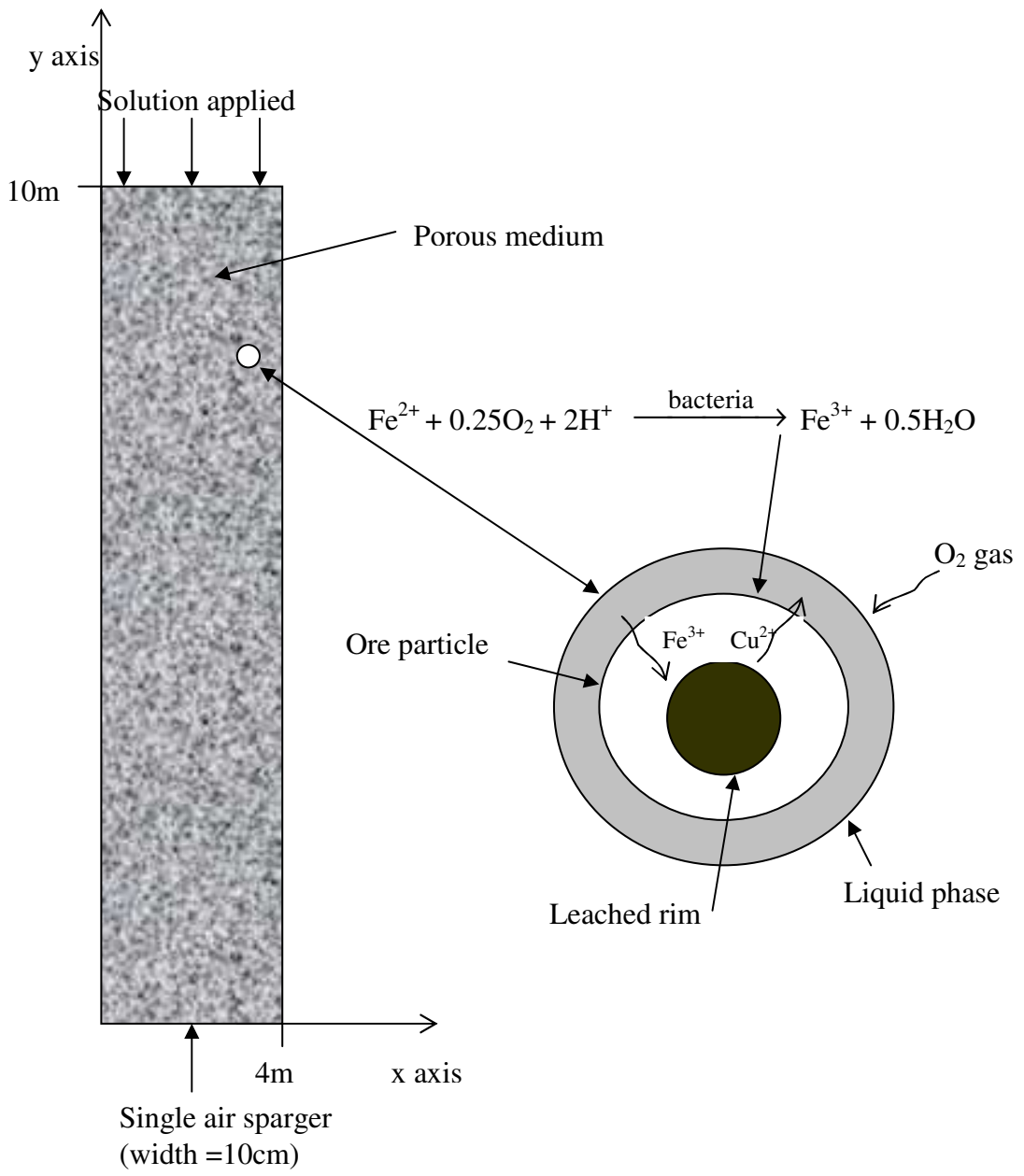

Figure 1: Schematic heap 
The scalar equation for the gas oxygen concentration $C_{g}$ at time $t$ (seconds) is

$$
\varepsilon_{g} \frac{\partial C_{g}}{\partial t}=\varepsilon_{g} D_{g} \nabla^{2} C_{g}-\varepsilon_{g} \nabla \cdot\left(\mathbf{v}_{g} C_{g}\right)+k_{L}\left(C_{L}-H_{e} C_{g}\right),
$$

where $k_{L}$ is the mass transfer rate, $H_{e}$ is Henry's constant, and $D_{g}$ is the diffusion (dispersion) coefficient for oxygen in gas.

The transport equation for species in the liquid is given by the advectiondiffusion equation for the species: dissolved oxygen $C_{L}\left(\mathrm{gL}^{-1}\right)$, bacteria $\phi$ (cells per L liquid), ferrous ions $C_{\mathrm{Fe}^{2+}}\left(\mathrm{gL}^{-1}\right)$ and ferric ions $C_{\mathrm{Fe}^{3+}}\left(\mathrm{gL}^{-1}\right)$ as

$$
\varepsilon_{L} \frac{\partial C_{i}}{\partial t}=\varepsilon_{L} D_{L} \nabla^{2} C_{i}+v_{L} \varepsilon_{L} \frac{\partial C_{i}}{\partial y}+S_{i},
$$

where $S_{i}$ is the source/sink term for the $i$ th species, and $D_{L}$ is the diffusion (dispersion) coefficient for oxygen in liquid, with $y$ the distance from the bottom of the heap. In porous media flow, the dispersion coefficient is usually proportional to the phase velocity and the dispersive length scale, with the latter being taken as the average ore particle (assuming homogeneous bed) size so that in the liquid phase

$$
D_{L}=2 v_{L} \delta,
$$

where $\delta$ is the average ore particle radius. In this work the molecular diffusion coefficient for the liquid phase is ignored, since it is typically much smaller than the dispersion term in (8).

The attached population of bacteria $\psi$ (cells per kg ore) which are attached to the stationary solid phase, satisfy

$$
\frac{\partial}{\partial t}\left(\varepsilon_{\text {ore }} \psi\right)=S_{\psi},
$$

where the ore bed density $\varepsilon_{\text {ore }}=\rho_{b} \varepsilon_{o}$, with $\rho_{b}$ the ore density, $\varepsilon_{o}$ the bed rock fraction, and the sum of the phase fractions satisfies

$$
\varepsilon_{o}+\varepsilon_{L}+\varepsilon_{g}=1,
$$


and $S_{\psi}$ is the source term for the attached bacteria population, given below. The source and sink terms for each species in equation (7) are now described, starting with the source term for the oxygen in the liquid phase [12]:

$$
S_{L}=-\mu \frac{0.25 M_{\mathrm{O}_{2}}}{M_{\mathrm{Fe}^{2+}} Y}\left(\varepsilon_{\mathrm{ore}} \psi+\varepsilon_{L} \phi\right)+k_{L}\left(H_{e} C_{g}-C_{L}\right),
$$

where $M$ are the molecular weights of the corresponding species, $Y$ is the yield coefficient (bacteria produced per kilograms of ferrous ions consumed) and the growth rate $\mu\left(s^{-1}\right)$ is given by the double Monod kinetics as

$$
\mu=\mu_{\max }\left(\frac{C_{L}}{K_{M, \mathrm{O}}+C_{L}}\right)\left(\frac{C_{\mathrm{Fe}^{2+}}}{K_{M, \mathrm{Fe}^{2+}}+C_{\mathrm{Fe}^{2+}}}\right)
$$

where $K_{M, \mathrm{O}}\left(\mathrm{gL}^{-1}\right)$ is the half growth rate constant for oxygen, $K_{M, \mathrm{Fe}}\left(\mathrm{gL}^{-1}\right)$ is the half growth rate constant for ferrous ion, and $\mu_{\max }\left(s^{-1}\right)$ is the maximum growth rate coefficient.

The source term for the bacteria in solution is

$$
S_{\phi}=\left(\mu-k_{\text {death }}\right) \varepsilon_{L} \phi-k_{1} \varepsilon_{L} \phi\left(1-\frac{\psi}{\psi_{\max }}\right)+k_{2} \varepsilon_{\text {ore }} \psi,
$$

and similarly the source term for the bacteria attached to the ore is

$$
S_{\psi}=\left(\mu-k_{\text {death }}\right) \varepsilon_{\text {ore }} \psi+k_{1} \varepsilon_{L} \phi\left(1-\frac{\psi}{\psi_{\max }}\right)-k_{2} \varepsilon_{\text {ore }} \psi,
$$

where $k_{\text {death }}$ is the death rate of the bacteria, $k_{1}$ is the rate of attachment, $k_{2}$ is the rate of detachment, and $\psi_{\max }$ the maximum population of bacteria that can attach to the ore per $\mathrm{kg}$ of ore. The second term in equations (13) and (14) corresponds to the transfer of bacteria from liquid phase to the ore surface, assuming the bacterial attachment is proportional to the bacteria number in solution, and is limited by the maximum number that may attach $\psi_{\max }$. The third term in equations (13) and (14) corresponds to the detachment of bacteria into the liquid phase and is proportional to the number 
of bacteria attached. This attachment/detachment model was first proposed by Tan et al. [14] in the context of bacterial attachment to sand in an aquifer.

The equations describing the ferric and ferrous ion concentration are derived from the stoichiometric equations (1), (2) and (3) as described by Neuburg et al. [12] are

$$
\begin{aligned}
& S_{\mathrm{Fe}^{2+}}=-\frac{\mu}{Y}\left(\varepsilon_{\mathrm{ore}} \psi+\varepsilon_{L} \phi\right)+\left(-\frac{4 M_{\mathrm{Fe}}}{M_{\mathrm{cps}}}-\frac{15 M_{\mathrm{Fe}}}{M_{\mathrm{py}}} F_{\mathrm{PY}}\right) R_{\mathrm{cps}}, \\
& S_{\mathrm{Fe}^{3+}}=\frac{\mu}{Y}\left(\varepsilon_{\mathrm{ore}} \psi+\varepsilon_{L} \phi\right)+\left(\frac{4 M_{\mathrm{Fe}}}{M_{\mathrm{cps}}}+\frac{14 M_{\mathrm{Fe}}}{M_{\mathrm{py}}} F_{\mathrm{PY}}\right) R_{\mathrm{cps}},
\end{aligned}
$$

where $F_{\mathrm{PY}}$ is the ratio of pyrite and copper sulfide leaching rates, and the rate of copper sulfide leaching $R_{\mathrm{cps}}=-\varepsilon_{\text {ore }} G \frac{d \alpha}{d t}$ with the shrinking core equation

$$
\frac{d \alpha}{d t}=\frac{3(1-\alpha)^{2 / 3} C_{\mathrm{Fe}^{3+}}}{\tau_{c}+6 \tau_{d}(1-\alpha)^{1 / 3}\left(1-(1-\alpha)^{1 / 3}\right)},
$$

where $\alpha$ is the copper fraction remaining in the ore, and

$$
\tau_{c}=\frac{\delta \varphi \rho_{b} M_{\mathrm{Fe}}}{\beta M_{\mathrm{ore}}}, \quad \tau_{d}=\frac{\delta^{2} \sigma G \varphi \rho_{b} M_{\mathrm{Fe}}}{D_{\mathrm{eff}} M_{\mathrm{ore}}},
$$

where $G$ is the grade of the ore, $\sigma$ is the stoichiometric coefficient, $\varphi$ is the particle shape factor, $\beta$ is the intrinsic rate of oxidation and $D_{\text {eff }}$ is the effective diffusion coefficient of the oxidant $\left(\mathrm{Fe}^{3+}\right)$ through the particle.

\subsection{Boundary and initial conditions}

Consider a heap of dimensions 4 by 10 metres, with the heap assumed to have liquid applied evenly to the top of the heap, whilst air is sparged via a single sparger in the middle of the heap, as shown in Figure 1. This geometry represents the section of heap above a single sparger, which are spaced at 4 metres, as is the case in practice. 
The gas and liquid flow rates are assumed to be constant at the inlets. The heap is assumed to be initially free of attached bacteria, but initially have concentration in solution $C_{o}=10^{14}$ bacteria $\mathrm{m}^{-3}$ liquid. Initially atmospheric levels of oxygen are assumed, with $1 \mathrm{gL}^{-1}$ ferrous and ferric ions in solution, and $\alpha=0$. The boundary conditions are: atmospheric levels of oxygen at the top and bottom of the heap in the liquid and gas phases respectively, with no added bacteria, and ferrous and ferric ion inflow of $1 \mathrm{gL}^{-1}$ each. At the bottom of the heap a zero gradient for the liquid scalars are assumed, and also for the gas phase at the top of the heap. The gas and liquid flow rates are assumed constant at the inlets. The sides of the heap are taken to be symmetries, representing a periodic section of the heap above a sparger, away from the sides of the heap.

\section{$2.3 \quad$ Numerical considerations}

The system of 10 partial differential equations (4-18) (with the equation of continuity) were discretized and solved using a computational fluid dynamics solver $C F X_{4.4}$ [1], with all the spatial derivatives approximated by central differences, which was stable because the mesh Peclét number is chosen to be less than 2 for the liquid and gas phases. The time derivatives were approximated with backward differences. The time step used was 1000 seconds, and the results showed insignificant differences when the time step was reduced by a factor of 10 . The Cartesian grid was rectangular with 40 by 400 cells in the $x$ and $y$ axes respectively. The results were found to be grid independent, with insignificant differences when the grid size was halved. The system of discretized equations was solved iteratively and the results are iteration independent (the normalized residuals are all less than $10^{-3}$ each time step). No more than 10 iterations per time step were needed for this convergence. 


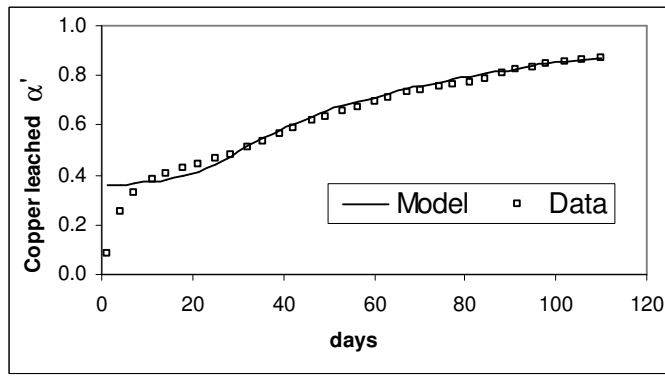

(a)

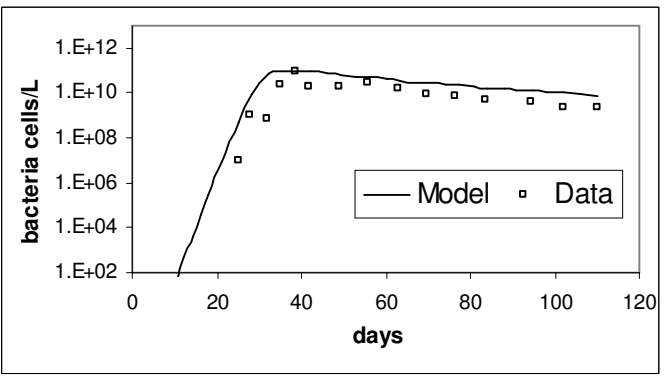

(b)

Figure 2: Data and model copper extraction (a) data and model bacteria concentration (b) versus time.

\section{Results and discussion}

\subsection{Experimental validation}

For validation purposes, an experimental data set is used from [8], a column bioleaching operation of low grade chalcocite ore mixed with pyrite, having weight grades $0.9 \%$ and $3.5 \%$ respectively, as well as acid soluble copper sulfide (presumably copper oxide), with $0.5 \%$ grade. The operation lasted 120 days, and was performed in a $5 \mathrm{~m}$ high by $10 \mathrm{~cm}$ diameter column (the details of the model validation can be found in [10]).

The acid soluble copper sulfide is assumed to have been flushed out very quickly with the acid in solution and is not included in the simulation. The experimental data in [8] includes the $0.5 \%$ acid soluble copper sulfide, so to compare the present model with the data, the model copper extracted from chalcocite $(\alpha)$ is added to the $0.5 \%$ acid soluble component to give the total copper extracted as $\alpha^{\prime}$ in Figure 2(a) instead of $\alpha$ as

$$
\alpha^{\prime}=\alpha \frac{0.9}{1.4}+\frac{0.5}{1.4},
$$




\begin{tabular}{cccc} 
Parameter & Value & Units & Reference \\
\hline$Y$ & $2.2 \times 10^{14}$ & bacteria $\left(\mathrm{kg} \mathrm{Fe}^{2+} \text { consumed }\right)^{-1}$ & {$[8]$} \\
$\varepsilon_{L}, \varepsilon_{g}$ & $0.2,0.2$ & - & {$[5]$} \\
$\mu_{\max }$ & $2.82 \times 10^{-5}$ & $\mathrm{sec}^{-1}$ & {$[6]$} \\
$k_{\text {death }}$ & $2.5 \times 10^{-6}$ & $\mathrm{sec}^{-1}$ & - \\
$k_{1}$ & $3.47 \times 10^{-5}$ & $\mathrm{sec}^{-1}$ & - \\
$k_{2}$ & $2.0 \times 10^{-7}$ & $\mathrm{sec}^{-1}$ & - \\
$K_{M, \mathrm{O}}$ & $7.6 \times 10^{-3}$ & $\mathrm{gL}^{-1}$ & {$[6]$} \\
$K_{M, \mathrm{Fe}}{ }^{2+}$ & $5.58 \times 10^{-3}$ & $\mathrm{gL}^{-1}$ & {$[6]$} \\
$F_{\mathrm{PY}}$ & 0.98 & - & - \\
$v_{g}$ & $1.1 \times 10^{-2}$ & $\mathrm{~ms}^{-1}$ & {$[8]$} \\
$v_{L}$ & $2.646 \times 10^{-5}$ & $\mathrm{~ms}^{-1}$ & {$[8]$} \\
$\delta, G$ & $0.01,0.9 \%$ & $\mathrm{~m}^{-}$ & {$[8]$} \\
$\beta$ & $1.30 \times 10^{-7}$ & $\mathrm{~ms}^{-1}$ & {$[12]$} \\
$\varepsilon_{\text {ore }}$ & 1410 & $\mathrm{gL}^{-1}$ & {$[6]$} \\
$D_{\text {eff }}$ & $9.5 \times 10^{-11}$ & $\mathrm{~m}^{2} \mathrm{~s}^{-1}$ & {$[15]$} \\
$\varphi, \sigma$ & $0.65,4$ & - & {$[12]$} \\
$\psi_{\max }$ & $7.8 \times 10^{12}$ & bacteria $\left(\mathrm{kg}^{-1} \text { ore }\right)^{-1}$ & {$[6]$} \\
$k_{L}$ & $6.94 \times 10^{-2}$ & $\mathrm{sec}^{-1}$ & {$[6]$} \\
\hline
\end{tabular}

TABle 1: Parameters used

In Figures 2(a)-(b) we see a good comparison between data and model predictions for total copper extracted $\left(\alpha^{\prime}\right)$ and effluent bacterial concentration. A greater discussion of the experimental validation can be found in [10].

\subsection{Model results}

For the parameters in Table 1 we present the results at several times in Figures 3,4 and 5 with (a)-(d) the 2D contour plots of copper leached, bacteria, oxygen and ferrous ions respectively. The results show the bacteria are ini- 


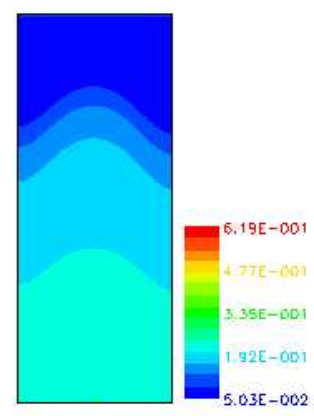

(a)

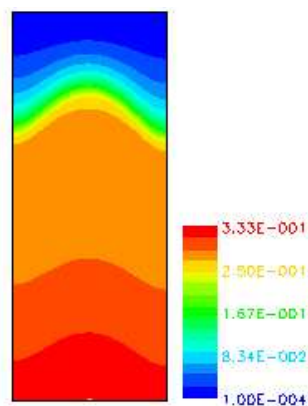

(b)

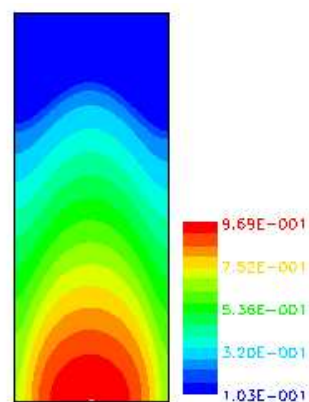

(c)

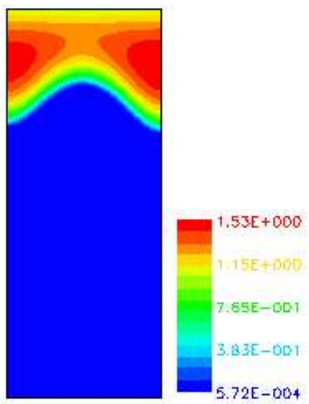

(d)

Figure 3: (a) Copper extracted $\alpha$ (b) bacterial concentration in solution (normalized by initial concentration $C_{o}=10^{14}$ bacteria $\mathrm{m}^{-3}$ solution) (c) oxygen in liquid (normalized by initial oxygen concentration), and (d) ferrous ions $\left(\mathrm{gL}^{-1}\right)$, at 23 days

tially limited by oxygen (at 23 days) in the upper section of the heap, see Figure $3(\mathrm{~b})$, where bacteria are present at very low concentration $\left(10^{-4} C_{o}\right)$ compared to the bottom of the heap, where the concentration is $0.33 C_{o}$. Hence ferric ions are not present for leaching at the top of the column, even though ferric is being fed into the column. However, Figure 5(b) shows that at 116 days, bacteria are no longer limited by oxygen in the upper section of the heap, where bacteria are present at high concentration $\left(0.17 C_{o}\right)$ compared to the bottom of the heap, with bacterial concentration $5.34 \times 10^{-2} C_{o}$. Hence ferric ions will now be available for leaching at the top of the column and leaching proceeds. Therefore copper leaching is found to occur from the bottom up.

The leaching from bottom up is best described in Figure 6, which shows the $1 \mathrm{D}$ line plot of the $2 \mathrm{D}$ plots at $x=2$ (the vertical centre line of the heap). Here we see that the lower sections of the heap are leached faster due to the higher bacterial concentration. However, in the lower portion of the heap, the rate of leaching slows and consequently the ferrous ion level drops, 


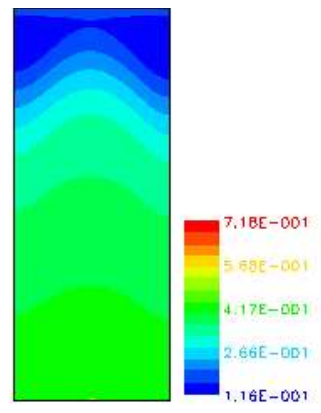

(a)

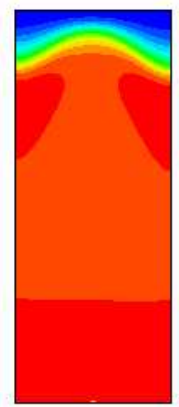

(b)

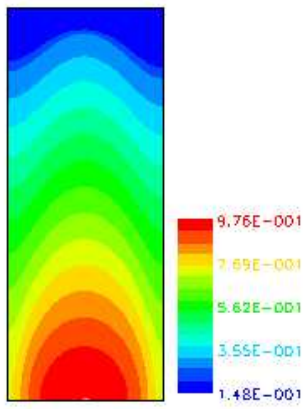

(c)

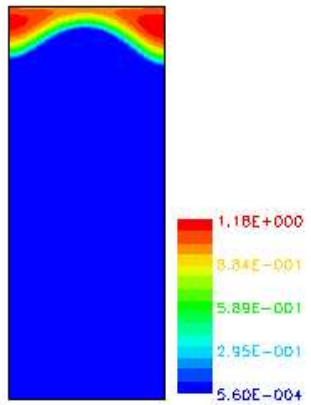

(d)

Figure 4: (a) Copper extracted $\alpha$ (b) bacterial concentration in solution

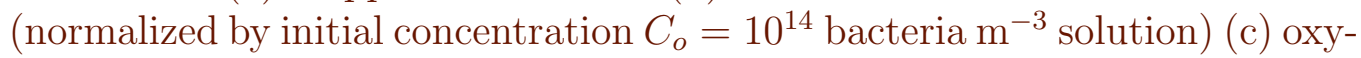
gen in liquid (normalized by initial oxygen concentration), and (d) ferrous ions $\left(\mathrm{gL}^{-1}\right)$, at 46 days

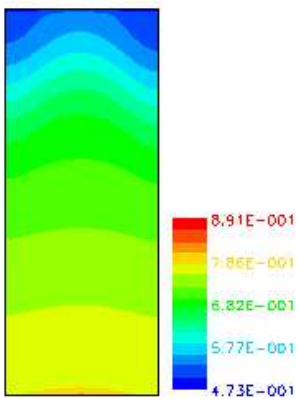

(a)

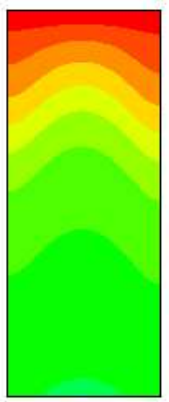

(b)

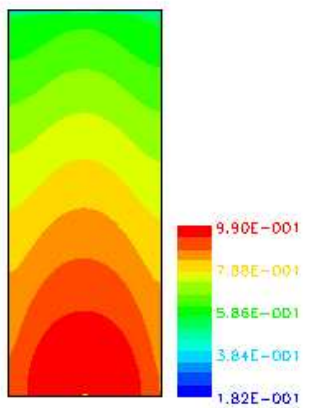

(c)

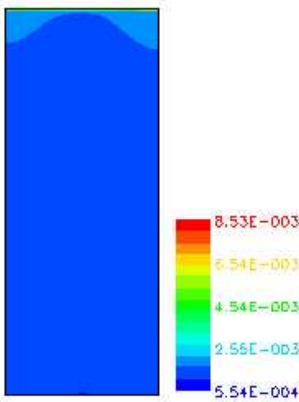

(d)

Figure 5: (a) Copper extracted $\alpha$ (b) bacterial concentration in solution (normalized by initial concentration $C_{o}=10^{14}$ bacteria $\mathrm{m}^{-3}$ solution) (c) oxygen in liquid (normalized by initial oxygen concentration), and (d) ferrous ions $\left(\mathrm{gL}^{-1}\right)$, at 116 days 


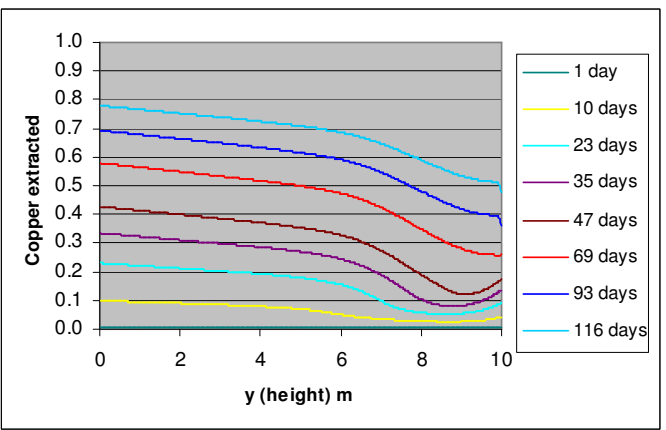

(a)

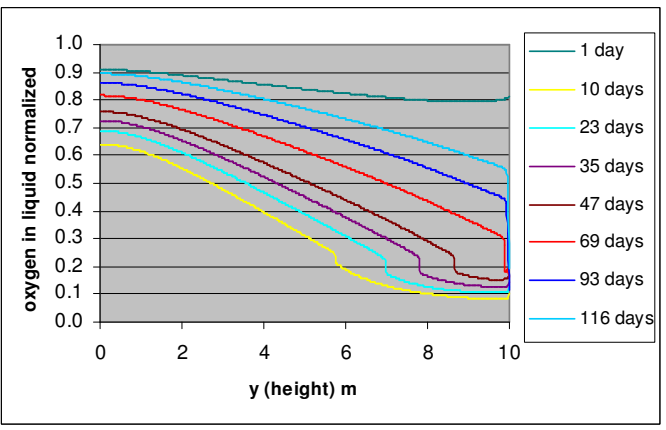

(c)

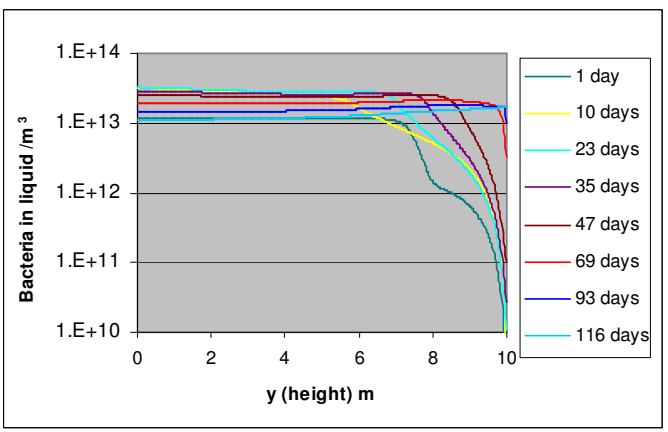

(b)

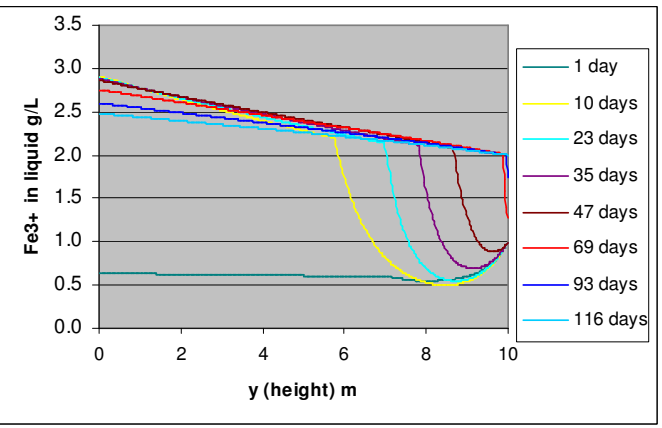

(d)

Figure 6: Line plots versus $y$, at $x=2 \mathrm{~m}$, of the variables (a) copper extracted $\alpha$ (b) bacterial concentration in solution (normalized by initial concentration $C_{o}=10^{14}$ bacteria $\mathrm{m}^{-3}$ solution) (c) oxygen in liquid (normalized by initial oxygen concentration), and (d) ferric ions $\left(\mathrm{gL}^{-1}\right)$, vs bed height $y$, at various times 
so that bacterial activity becomes limited by ferrous ions. As a result, the bacterial concentration drops and less oxygen is used in the lower section of the heap, and more is available to the previously oxygen limited top section of the heap. Consequently, bacteria, which were still present in the upper section in low levels, regenerate and come up to levels needed for sufficient ferric ion production, for copper leaching. This process causes a leaching of the heap in a bottom up fashion, so that eventually all of the heap is leached.

The distribution of bacteria has a 2D conical type shape, see Figure 3(b), since the region of oxygen limitation has this shape from the single sparger, with a concentration of oxygen less than around $15 \%$ (of atmospheric concentration) being limiting. The copper extracted therefore reflects this, since copper extraction is proportional to ferric ion concentration, and ferric ions are produced by bacteria.

\section{Conclusion}

The model was used to investigate the effect of poor oxygenation (in 2D) in heap bioleaching of copper sulfide. It was found that under oxygen limitation, the heap is leached from the bottom up progressively, as the oxygen became available to the upper regions, after the bottom regions have been leached. The 2D gas flow model showed that oxygen has a 2D distribution throughout the heap, with the conical shape also reflecting in the bacteria concentration, and consequently also other variables including the copper extracted. Further work should incorporate several more aspects: the effect of jarosite precipitation, 2D liquid flow, acidity, and the effects of thermal variations within a heap.

Acknowledgment: The help of Peter Witt with $C F X$ and Helen Watling with experimental aspects, Jakub Bujalski with modelling aspects, as well as 
funding from an Australian Postgraduate Award and a CSIRO top-up scholarship (for M. J. Leahy) was greatly appreciated.

\section{References}

[1] AEA Technology, CFX4.4 Solver. CFX4.4 On-line documentation. AEA Technology, Harwell Laboratory, Oxfordshire, UK, 2001. C448

[2] A. Al-Khlaifat and H. Arastoopur. Simulation of two-phase flow through low-permeability porous media. In AEA technology international user conference '97, 1997. C443

[3] R. W. Bartlett. Solution mining leaching and fluid recovery of minerals, 2nd ed., OPA, 1998. C442

[4] C. R. Bennett, M. Cross, T. N. Croft, J. L. Uhrie, C. R. Green, and J. E. Gebhardt. A comprehensive copper stockpile leach model: background and model formulation. In C. A. Young, A. W. Alfantazi, C. G. Anderson, D. B. Dreisinger, B. Harris, and A. James, editors, Hydrometallurgy 2003, pages 315-328. TMS, 2003. C441

[5] S. C. Bouffard and D. G. Dixon. Investigative study into the hydrodynamics of heap leaching processes. Met. Mat. Trans. B, 32B:763-776, 2001. C441, C450

[6] S. C. Bouffard and D. G. Dixon. Mathematical modelling of pyritic refractory gold ore heap biooxidation: model development and isothermal column simulations. In C. A. Young, A. W. Alfantazi, C. G. Anderson, D. B. Dreisinger, B. Harris, and A. James, editors, Hydrometallurgy 2003, pages 275-288. TMS, 2003. C450

[7] D. G. Dixon. Heap leach modelling-the current state of the art. In C. A. Young, A. W. Alfantazi, C. G. Anderson, D. B. Dreisinger, 
B. Harris, and A. James, editors, Hydrometallurgy 2003, pages 289-314. TMS, 2003. C441

[8] D. G. Dixon and J. Petersen. Comprehensive modelling study of chalcocite column and heap bioleaching. In D. B. Dreisinger P. A. Riveros, D. G. Dixon and J. Menacho, editors, Copper 2003-Cobre 2003 Volume VI - Hydrometallurgy of Copper (Book 2), pages 493-515, 2003. C441, C442, C449, C450

[9] B. Escobar, E. Jedlicki, J. Wiertz, and T. Vargas. A method for evaluating the proportion of free and attached bacteria in the bioleaching of chalcopyrite with Thiobaccilus ferrooxidans. Hydrometallurgy, 40:1-10, 1996. C441

[10] M. J. Leahy, P. Schwarz, and M. R. Davidson. A column bioleaching model for chalcocite: an investigation of oxygen limitation and bacterial inoculation on leaching. In BACMIN Proceedings, pages 41-47, Bendigo, Australia, 8-10 November 2004. AusIMM. C449, C450

[11] G. Meruane and T. Vargas. Bacterial oxidation of ferrous iron by Acidithiobacillus ferrooxidans in the $\mathrm{pH}$ range 2.5-7.0. Hydrometallurgy, 71:149-158, 2003. C441

[12] H. J. Neuburg, J. A. Castillo, M. N. Herrera, J. V. Wiertz, T. Vargas, and R. Badilla-Ohlbaum. A model for the bacterial leaching of copper sulphide ores in pilot-scale columns. Int. J. Min. Proc., 31:247-264, 1991. C441, C443, C446, C447, C450

[13] M. Sidborn and L. Moreno. Model for bacterial leaching of copper sulphides by forced aeration. Proceedings of the 15th International Biohydrometallurgy Symposium (IBS 2003), 2003. C442

[14] Y. Tan, J. T. Gannon, P. Baveye, and M. Alexander. Transport of bacteria in an aquifer sand: Experiments and model simulations. Wat. Resour. Res., 30(12):3243-3252, 1994. C447 
[15] F. Zeballos, O. Barbosa Filho, and R. Jose de Carvalho. Mathematical modeling of the chemical and bacterial leaching of copper ores in stack. In Proceedings of the 15th International Biohydrometallurgy Symposium (IBS 2003), paper 32, 2003. C450 